\title{
Glomerular thrombi in renal allografts associated with cyclosporin treatment
}

\author{
GH NEILD,${ }^{*} \ddagger$ ROWENA REUBEN, $\uparrow$ RB HARTLEY, $\dagger$ JS CAMERON* \\ From the *Renal Unit, Department of Medicine, Guy's Hospital, and the †Pathology Department, Guy's \\ Medical School, London SE1
}

SUMMARY We have found glomerular capillary thrombi or afferent arteriolar thrombosis in eight renal biopsy specimens from seven renal allograft recipients. All patients were receiving cyclosporin and prednisolone. Biopsies were performed either routinely one and four weeks after transplantation or during periods of renal dysfunction. None of the patients whose biopsy material contained glomerular thrombi was considered, in retrospect, to have been undergoing rejection at the time of biopsy. Thrombi consisted of finely granular material partially obstructing glomerular capillaries. By light microscopy the staining characteristics of the thrombi were compatible with platelet-fibrin aggregates, and this was confirmed by immunoperoxidase examination. Such thrombi have not previously been seen in biopsy material from patients treated with prednisolone and azathioprine, except rarely associated with acute vascular rejection. In none of these patients was there haematological evidence of the haemolytic uraemic syndrome as has been reported in bone marrow recipients treated with cyclosporin.

Glomerular thrombosis and the haemolytic uraemic syndrome have been reported in bone marrow recipients receiving cyclosporin treatment.' A more extensive microvascular injury simulating thrombotic thrombocytopenic purpura has also been reported in such patients. ${ }^{2}$

We report the appearance of glomerular thrombi in renal allografts, the recipients of which were receiving cyclosporin and prednisolone and in whom there was neither histological nor clinical evidence of rejection. These changes were noted in biopsy material obtained either routinely one and four weeks after transplantation or because of renal dysfunction which was subsequently considered to be due to cyclosporin toxicity.

\section{Material and methods}

Data from individual patients are shown in Table 1. All patients who received cadaver grafts had been given five or more units of $\mathbf{1 0}$ day old blood before transplantation. Patients' serum samples were screened for HLA antibodies by routine mic-

$\ddagger$ Present address: Institute of Urology, St Philip’s Hospital, Sheffield Street, London WC2.

Accepted for publication 21 November 1984 rocytotoxicity testing against a panel of 66 typed individuals, and at the time of transplantation all patients had a negative cross match with donor lymphoid cells. ${ }^{3}$ Cyclosporin (Sandimmun, Sandoz Ltd) was given orally as a single dose in the following regimen: $14 \mathrm{mg} / \mathrm{kg} /$ day for 14 days, then $12 \mathrm{mg} / \mathrm{kg} /$ day until day $30,10 \mathrm{mg} / \mathrm{kg} /$ day until day $60,8 \mathrm{mg} /$ $\mathrm{kg} /$ day until day 90 , then $6 \mathrm{mg} / \mathrm{kg} /$ day. Prednisolone was given orally at a starting dosage of $15 \mathrm{mg} / \mathrm{m}^{2}$, which was reduced to $10 \mathrm{mg} / \mathrm{m}^{2}$ at 6 months. Whole blood cyclosporin concentrations $(\mu \mathrm{g} / \mathrm{l})$ were measured by radioimmunoassay (RIA) using the Sandoz RIA kit. Cyclosporin was given at $6.00 \mathrm{pm}$, and fasting blood concentrations were measured at $7.00 \mathrm{am}$. Renal function (plasma urea and creatinine), plasma biochemistry, and haematological indices were monitored as previously described. ${ }^{4}$

Renal biopsies were performed routinely after one week and four weeks and for episodes of deteriorating renal function ("renal dysfunction"). An episode of renal dysfunction was defined as a rise in plasma creatinine concentration of more than $20 \%$ above the preceeding baseline value. Episodes of dysfunction which were considered to be due to rejection were treated with pulses of $1 \mathrm{~g}$ of methylprednisolone on three consecutive days. The routine biopsies were performed as part of an investigation into the diagnosis of renal allograft dysfunction that 
Table 1 Clinical and immunological data

\begin{tabular}{|c|c|c|c|c|c|c|c|}
\hline Patient no & Original renal disease & Sex & Age & Blood group & $\begin{array}{l}\text { Tissue type } \\
\text { Recipient }\end{array}$ & Donor & $\begin{array}{l}\text { HLA antibodies* } \\
(\%)\end{array}$ \\
\hline 1 & $\begin{array}{l}\text { Idiopathic crescentic } \\
\text { glomerulonephritis }\end{array}$ & $\mathbf{M}$ & 52 & $A+v e$ & $3,-, 7,40$ & $2,30,12,13$ & 9 \\
\hline $\begin{array}{l}2 \\
3 \\
4 a \\
b\end{array}$ & $\begin{array}{l}\text { Reflux } \\
\text { Henoch-Schönlein } \\
\text { Chronic glomerulonephritis }\end{array}$ & $\begin{array}{l}\mathbf{M} \\
\mathbf{M} \\
\mathbf{M}\end{array}$ & $\begin{array}{l}26 \\
32 \\
61\end{array}$ & $\begin{array}{l}O+v e \\
O-v e \\
O+v e\end{array}$ & $\begin{array}{l}2,9,5,16 \\
1, \frac{1}{3}, 17 \\
2,3,12,22\end{array}$ & $\begin{array}{l}2,-\frac{5}{9}, \frac{}{7} \\
3, \frac{7}{12},-\frac{1}{3},\end{array}$ & $\begin{array}{r}56 \\
5 \\
6\end{array}$ \\
\hline $\begin{array}{l}5 \\
6 \\
7\end{array}$ & $\begin{array}{l}\text { Henoch-Schönlein } \\
\text { Familial amyloid } \\
\text { Reflux }\end{array}$ & $\begin{array}{l}\mathbf{M} \\
\mathbf{M} \\
\mathbf{F}\end{array}$ & $\begin{array}{l}11 \\
54 \\
45\end{array}$ & $\begin{array}{l}\mathrm{O}+\mathrm{ve} \\
\mathrm{AB}+\mathrm{ve} \\
\mathrm{AB}+\mathrm{ve}\end{array}$ & $\begin{array}{l}1,11,27,5 \\
2,19,7,44 \\
2,28,44,63\end{array}$ & $\begin{array}{l}1,2,27,44 \\
1,3,7,8 \\
3,24,14,44\end{array}$ & $\begin{array}{r}0 \\
36 \\
70\end{array}$ \\
\hline
\end{tabular}

*All recipients had a negative cross match.

$\%=$ percentage of cross reaction with normal panel lymphocytes; highest pretransplant value.

$\mathbf{M}=$ male, $\mathbf{F}=$ female.

we initiated when we started to use cyclosporin. As part of our policy, during the study we were not using the cyclosporin concentrations to influence our clinical management of renal dysfunction.

Renal biopsies were performed using a modified Vim-Silverman needle. Part of the specimen was fixed in $10 \%$ neutral, phosphate buffered formolsaline, embedded in paraffin wax, and processed for light microscopy as previously described. ${ }^{4}$ Sections were stained with haematoxylin and eosin, periodic acid Schiff, Martius scarlet blue, elastic van Gieson, and methenamine silver. Paraffin embedded sections were also processed for immunoperoxidase using the peroxidase-antiperoxidase method. ${ }^{5}$ Unless stated otherwise, all reagents were obtained from Dakopatts, Denmark. Sections were stained for fibrin/fibrinogen related antigens (FRA), factor XIIIa (Behringwerke AG), platelets (antithrombocyte antibody), and albumin as follows. The sections were dewaxed and then incubated with $0.05 \%$ pronase (Protease type VII, Sigma) in phosphate buffered saline (PBS) for $1 \mathrm{~h}$ at $37^{\circ} \mathrm{C}$. After incubation the sections were washed in water and PBS and incubated with 1/5 normal swine serum in PBS for $10 \mathrm{~min}$. They were then incubated with the optimum dilution of the respective rabbit antiserum for 30 min. After another wash, endogenous peroxidase activity was blocked by immersing the sections in $1 \%$ hydrogen peroxide in methanol for $30 \mathrm{~min}$. Sections were again washed, then incubated with 1/50 swine antirabbit immunoglobulin for $30 \mathrm{~min}$, and this was followed by an incubation in $1 / 100$ rabbit PAP. Peroxidase was developed with diaminobenzidine. Sections were counterstained with Mayer's haemalum and then dehydrated, cleared, and mounted. Sections stained for factor XIIIa did not need to be pronase digested. For each test section a negative control was prepared by using the adjacent section and omitting the primary antibody. The specificities of the anti-FRA and factor XIIIa antibody were shown by absorbing the respective antisera with fibrin prepared from platelet poor plasma. Sections of human placenta were used as positive controls in each run.

\section{Results}

The clinical and immunological data of individual patients are shown in Tables 1 and 2 . No patient had evidence of haemolysis, red cell fragmentation, or

Table 2 Data at time of biopsy

\begin{tabular}{|c|c|c|c|c|c|c|c|}
\hline $\begin{array}{l}\text { Patient } \\
\text { no }\end{array}$ & $\begin{array}{l}\text { Time } \\
\text { (days)* }\end{array}$ & Reason & $\begin{array}{l}\text { Creatinine } \\
\text { concentration } \\
(\mu \text { mol/l) }\end{array}$ & $\begin{array}{l}\text { Cyclosporin } \\
\text { concentration } \\
(\mu \mathrm{g} / \mathrm{l})\end{array}$ & $\begin{array}{l}\text { Cyclosporin } \\
\text { dosage } \\
(\mathrm{mg} / \mathrm{kg})\end{array}$ & Other drugs $\ddagger$ & $\begin{array}{l}\text { Creatinine } \\
\text { concentration } \\
\text { after } 120 \text { dow } \\
(\mu \mathrm{mol} / \mathrm{l})\end{array}$ \\
\hline $\begin{array}{l}1 \\
2 \\
3 \\
4 a \\
b \\
5 \\
6 \\
7\end{array}$ & $\begin{array}{r}9 \\
34 \\
9 \\
28 \\
77 \\
17 \\
33 \\
15\end{array}$ & $\begin{array}{l}\text { Routine } \\
\text { Dysfunction } \\
\text { Routine } \\
\text { Routine } \\
\text { Dysfunction } \\
\text { Dysfunction } \\
\text { Dysfunction } \\
\text { Dysfunction }\end{array}$ & $\begin{array}{l}327 \\
310 \\
120 \\
120 \\
150 \\
\text { HD } 8 \\
340 \\
228\end{array}$ & $\begin{array}{r}1539 \\
1400 \\
2000 \\
1200 \\
>2000 \\
755 \\
>2000 \\
1051\end{array}$ & $\begin{array}{r}14 \\
10 \\
14 \\
12 \\
8 \\
10 \\
10 \\
12\end{array}$ & $\begin{array}{l}\text { Isosorbide, prazosin } \\
\text { Prazosin, frusemide } \\
\text { Captopril, nifedipine } \\
\text { None } \\
\text { Digoxin, warfarin } \\
\text { None } \\
\text { Cimetidine, Septrin } \\
\text { Isoniazid, Septrin }\end{array}$ & $\begin{array}{l}110 \\
160 \\
175 \\
160 \\
120 \\
240 \\
140\end{array}$ \\
\hline $\begin{array}{l}\text { *Days a } \\
\text { †Cyclosp } \\
\ddagger \text { Other } \\
\S \mathrm{HD}=\end{array}$ & $\begin{array}{l}\text { r transpla } \\
\text { rin = higl } \\
\text { lgs = oth } \\
\text { haemodi }\end{array}$ & $\begin{array}{l}\text { st concentratic } \\
\text { than prednisc } \\
\text { ysis; non-func }\end{array}$ & $\begin{array}{l}\text { ue in week pre } \\
\text { and cyclosporir } \\
\text { ince transplant }\end{array}$ & biopsy. & $\cdots-$ & & $\begin{array}{l}\text { Q } \\
\text { 우 } \\
\text { O } \\
\frac{0}{2} \\
\frac{1}{2}\end{array}$ \\
\hline
\end{tabular}


Table 3 Histopathological data

\begin{tabular}{|c|c|c|c|c|c|c|c|}
\hline \multirow[t]{2}{*}{ Patient no } & \multicolumn{3}{|c|}{ Glomeruli } & \multirow{2}{*}{$\begin{array}{l}\text { Glomerular } \\
\text { proliferation }\end{array}$} & \multicolumn{2}{|l|}{ Interstitial } & \multirow{2}{*}{$\frac{\text { Vessels }}{\text { Cyclosporin vasculopathy }}$} \\
\hline & $\begin{array}{l}\text { Total } \\
\text { number }\end{array}$ & $\begin{array}{l}\text { Number } \\
\text { obsolete }\end{array}$ & $\begin{array}{l}\text { Number with } \\
\text { thrombi }\end{array}$ & & Infiltrate & Oedema & \\
\hline $\begin{array}{l}1 \\
2 \\
3 \\
4\end{array}$ & $\begin{array}{l}13 \\
27 \\
24 \\
22 \\
14 \\
24 \\
33 \\
21\end{array}$ & $\begin{array}{l}2 \\
0 \\
0 \\
2 \\
0 \\
0 \\
0 \\
0\end{array}$ & $\begin{array}{l}3 \\
4 \\
4 \\
3 \\
2 \\
1 \\
2 \\
1\end{array}$ & $\begin{array}{l}+ \\
++ \\
0 \\
0 \\
+ \\
0 \\
+ \\
+\end{array}$ & $\begin{array}{l}\text { Foci }+ \\
\text { Diffuse }+ \\
\text { Rare foci }+ \\
\text { Foci }+ \\
\text { Foci }+ \\
0 \\
\text { Foci }+ \\
\text { Diffuse }+\end{array}$ & $\begin{array}{l}\text { Diffuse }+ \\
\text { Foci }+ \\
0 \\
\text { Foci }+ \\
\text { Foci }+ \\
0 \\
\text { Foci }+ \\
\text { Foci }+\end{array}$ & $\begin{array}{l}0 \\
+ \\
+ \\
0 \\
+++ \\
++ \\
++ \\
+++\end{array}$ \\
\hline
\end{tabular}

Obsolescent: complete collapse of capillary tuft.

Proliferation: mononuclear or polymorphonuclear neutrophils or both in capillary loops. $+=2-5$ cells/glomerulus; $++=5-10$ cells glomerulus.

Intiltrate: interstitial infiltrate of mononuclear cells. $+=$ mild,$++=$ moderate,$+++=$ severe.

Oedema: interstitial oedema; score as per infiltrate.

Vasculopathy: $+=$ occasional vascuolisation of cells plus slight hyalinosis (see text). $++=$ vacuolisation and hyalinosis. $+++=$ vacuolisation, hyalinosis and hypertrophy of arteriolar wall. $++\dot{+}+=$ as above, plus gross obstruction of arteriolar lumen.

thrombocytopenia either at the time of biopsy or during the period of dysfunction.

These eight biopsies were from a total of 72 biopsies taken from 30 renal allografts over a nine month period. Three patients had stable renal function and four patients had deteriorating renal function ("dysfunction"). The eighth patient (patient 5) had had no function after his transplant. His kidney was well perfused, as judged by radionucleotide scanning ( ${ }^{99} \mathrm{Tm}$-DTPA), and he was thought to have acute tubular necrosis. After his biopsy, which showed no evidence of rejection, his cyclosporin dosage was reduced and the graft started to function. Three of the four patients with dysfunction were treated with methylprednisolone. Of these three patients, one had no response to methylprednisolone and the other two also had scheduled reductions in their cyc- losporin dosages at the same time. Our decision to treat for rejection was based partly on the presence of cellular infiltrate in the biopsies, but with hindsight we would not now interpret their cellular infiltration as rejection. Thus, in retrospect, we would not consider these episodes of dysfunction as being due to rejection.

The histopathological findings are shown in Table 3 . When thrombi were seen they often affected only one or two capillary loops in one or two glomeruli. Thrombi consisted of finely granular material partly occluding capillary loops (Figs. 1 and 2). This material was sometimes associated with one or more phagocytic mononuclear cells (Figs. 1 and 2). The material was eosinophilic, periodic acid Schiff positive, and stained predominantly blue with Martius scarlett blue. Immunoperoxidase examination

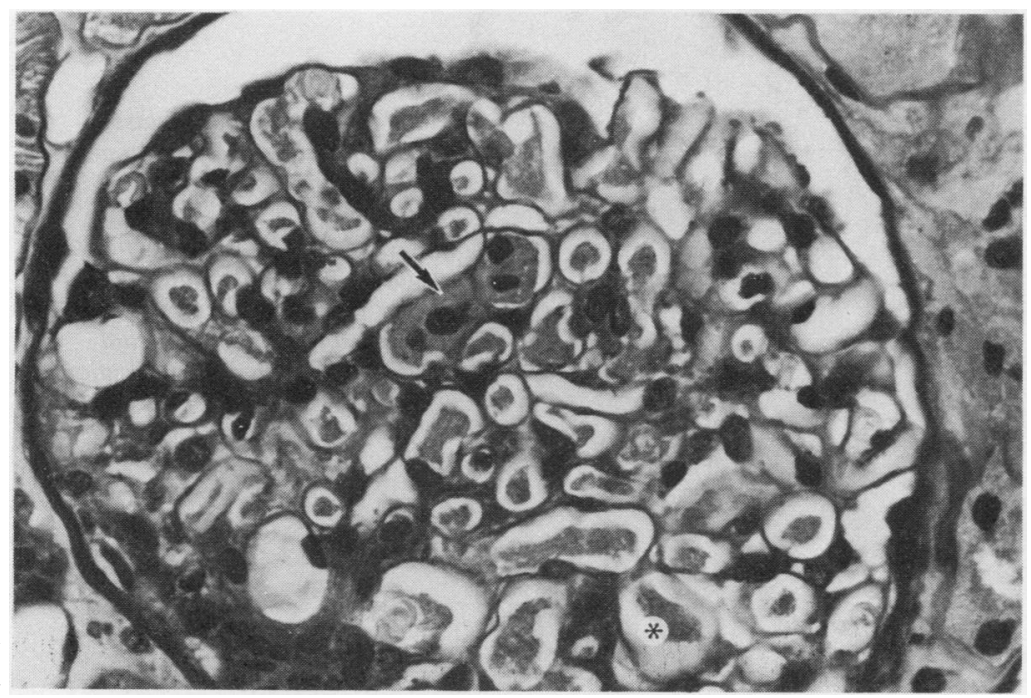

Fig. 1 Several glomerular capillary loops are partly occluded by finely granular material $\left({ }^{*}\right)$. In one capillary, this material is associated with mononuclear cells ( $\uparrow)$. Periodic acid Schiff. Original magnification $\times 510$. 


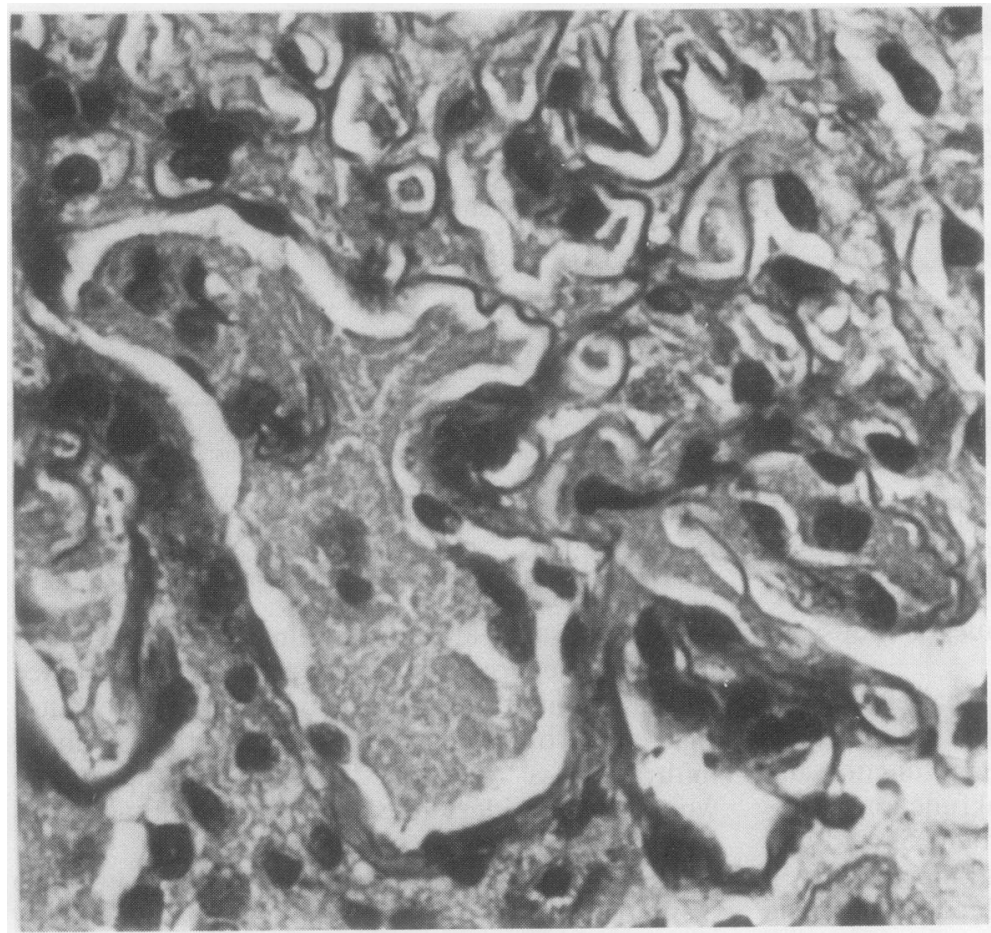

Fig. 2 Arteriole at glomerular hilum is partly occluded by large thrombus of aggregated mononuclear cells and amorphous material. Periodic acid Schiff. $\times$ 510.

showed the presence of FRA (Fig. 3), factor XIIIa, and platelets. The material did not stain for albumin. ticles were all of a size similar to platelets, stained In two cases (patients 2 and $4 \mathrm{~b}$ ) capillaries were blue with Martius scarlett blue, and reacted with partly occluded by aggregates of particles. The parantithrombocyte antibody (Fig. 4). In one case (patient 1), glomerular infarction and collapse was

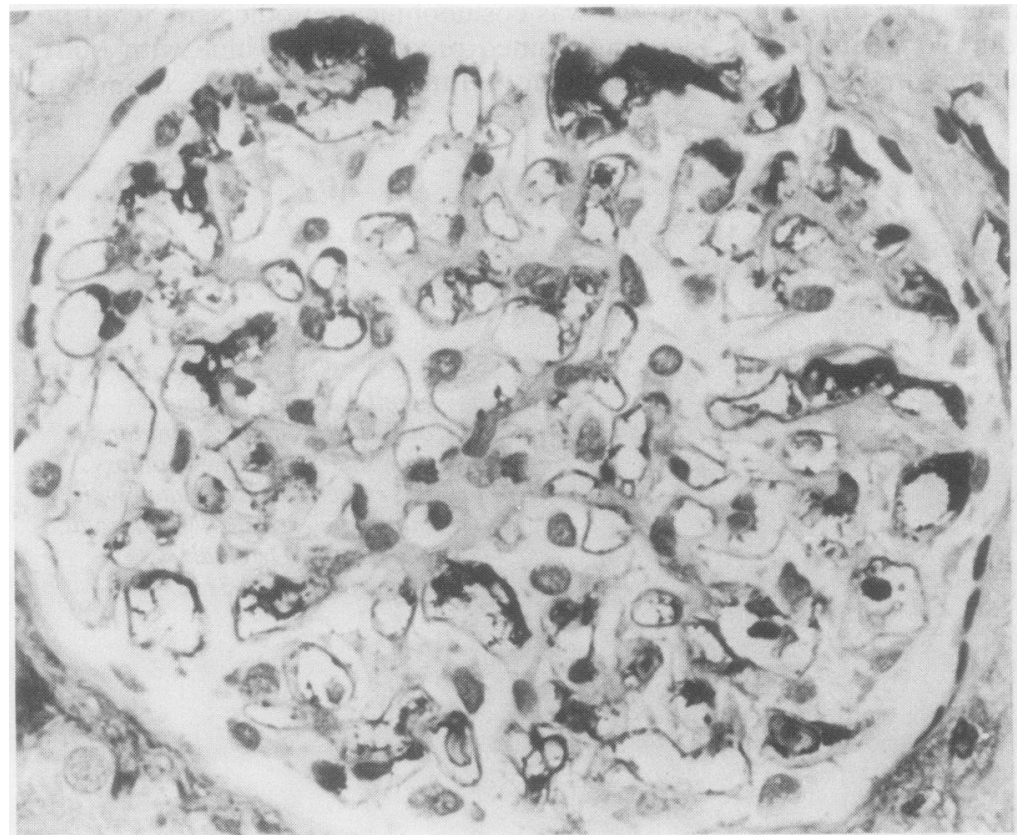

Fig. 3 Immunoperoxidase reaction staining for fibrinogen related antigens. Several capillary loops are partly occluded by material staining strongly positive (black) in this reaction. In other loops the material appears restricted to a subendothelial position. Original magnification $\times$ 510. 


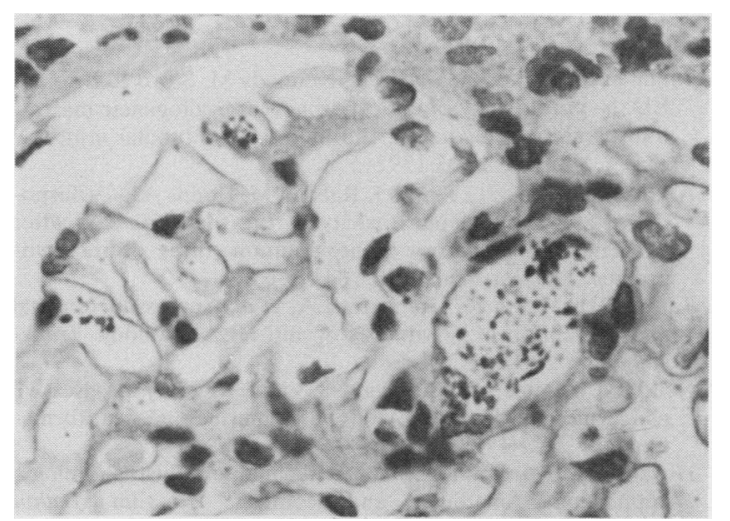

Fig. 4 Immunoperoxidase reaction staining for platelets. Three different sized capillary loops contain aggregates of platelet sized particles, which react positively with antithrombocyte antibody. Original magnification $\times 510$.

due to afferent arteriolar thrombosis. The material obstructing the afferent arteriole stained red and yellow with Martius scarlett blue, which suggested fresh fibrin like material. ${ }^{6}$ In another case (patient 2) a glomerulus was thrombosed with the capillary loops congested with erythrocytes. Immunoperoxidase examination showed the presence of FRA and factor XIIIa around these stagnant red cells.

Three biopsies showed a number of obsolescent glomeruli in which the glomerular tufts were totally ischaemic and had collapsed. In one of these cases (patient 4a) two glomeruli were partly collapsed and the loops were congested with red cells. A number of glomeruli, without thrombi, showed increased number of mononuclear cells or neutrophils or both present in capillary loops. In three biopsies a number of glomeruli showed apparent endocapillary proliferation (loss of capillary lumina), and a slight but diffuse increase in mesangial matrix. Although capillary thrombi were not identified by light microscopy, the capillaries were shown by immunoperoxidase to contain subendothelial deposits of FRA and factor XIIIa.

In all the biopsy material interstitial oedema and interstitial mononuclear cell infiltrates were also assessed (Table 3). Arteriolar lesions (vasculopathy) associated with cyclosporin A therapy, as described by Mihatsch et $a l,{ }^{7}$ were assessed. These consisted of hyalinosis, hypertrophy of arteriolar walls, and vacuolisation of endothelial and smooth muscle cells (Table 3).

\section{Discussion}

There were several surprising features about the glomerular thrombi. Firstly, they were often inci- dental findings in routine biopsies. Secondly, in the two most striking cases they were seen in biopsy material taken routinely after one week, and in both cases afferent arteriolar thrombosis was the conspicuous lesion rather than glomerular capillary thrombosis. Thirdly, in no instance was there evidence of a fall in platelet count or haemoglobin concentration or evidence of red cell fragmentation as has been reported after bone marrow transplantation. ${ }^{2}$ Our particular interest in glomerular thrombosis associated with cyclosporin treatment predates the report of glomerular thrombosis and haemolytic uraemic syndrome following bone marrow transplantation. During experiments in which rabbits with acute serum sickness were treated with high doses of cyclosporin $(25 \mathrm{mg} / \mathrm{kg} /$ day $)$ we noted that the rabbits developed renal lesions characterised by glomerular capillary thrombosis and infarction. ${ }^{8}$ In severe cases rabbits became oliguric and developed macroscopic cortical infarction. In such animals glomerular capillaries were completely occluded by dense amorphous material with the staining characteristics of fibrin-bright red with Martius scarlett blue, periodic acid Schiff positive, and intensely eosinophilic. In similar experiments, when rabbits were given lower doses of cyclosporin $(15 \mathrm{mg} / \mathrm{kg} /$ day), thrombi were much less conspicuous and were initially overlooked. As we recognised the range of changes that occurred in these experiments, we saw that in the mildest cases the thrombi consisted of loose, amorphous, eosinophilic material partly occluding glomerular capillaries. The thrombi were seen most readily when pronase digested paraffin sections were stained for fibrinogen (fibrin related antigens) by the immunoperoxidase technique. These less conspicuous thrombi were similar to the thrombi that we have seen in the renal allografts.

The different forms of glomerular thrombosis found in these eight biopsies were all similar to those described both in the haemolytic uraemic syndrome" and in the haemolytic uraemic like syndrome following bone marrow transplantation.' ${ }^{\prime}$ We stained the thrombi not just for fibrin related antigens but also for factor XIIIa. The presence of XIIIa signifies that the fibrin present is cross linked. ${ }^{10}$ When glomerular thrombi were seen after bone marrow transplantation, electron microscopical examination showed the thrombi consisting of platelets and fibrin. ${ }^{1}$

It may seem surprising that other groups have not reported glomerular thrombi. In renal allograft recipients receiving cyclosporin there may be an increased incidence of renal artery thrombosis compared with patients receiving conventional treatment with prednisolone and azathioprine," but there are no reports of glomerular thrombosis occurring in the absence of vascular rejection. 
Glomerular thrombosis is a feature of rejection, ${ }^{12}$ particularly acute vascular rejection, and glomerular thrombi, if seen, may have been interpreted as rejection. In the first clinical report of the efficacy of cyclosporin in renal transplantation Calne et al ${ }^{13}$ illustrated a case in which "vascular rejection" at day 7 was manifested by "haemorrhagic necrosis of the glomerular tuft."

In what way might cyclosporin affect the kidney and lead to glomerular capillary thrombosis? In the haemolytic uraemic syndrome vascular tissue from some patients is unable to produce prostacyclin. ${ }^{14}$ Prostacyclin is both a potent vasodilator and the most potent inhibitor of platelet aggregation. ${ }^{15}$ It is also the major arachidonic acid metabolite produced by vascular endothelium ${ }^{15}$ and by the glomerulus. ${ }^{16}$ Normal plasma contains a factor which stimulated endothelial cells to produce prostacyclin ${ }^{17}$; this factor is known as prostacyclin stimulating factor. Remuzzi et al ${ }^{14}$ showed that plasma from some patients with haemolytic uraemic syndrome had a pronounced loss of prostacyclin stimulating factor activity. In collaboration with Remuzzi's group we showed that when rabbits were treated with high doses of cyclosporin $(25 \mathrm{mg} / \mathrm{kg} /$ day $)$ there was a profound loss of prostacyclin stimulating factor activity in their plasma. ${ }^{18}$ We have proposed that when endothelial injury occurs in the absence of prostacyclin there may be an uncontrolled platelet aggregation leading to capillary thrombosis. ${ }^{18}$

In summary, this report describes another example of vascular injury associated with cyclosporin treatment. Although glomerular thrombi were seen in these cases, there was no evidence of the more severe and diffuse injuries, with microangiopathic haemolytic anaemia and thrombocytopenia, that have occurred after bone marrow transplantation. ${ }^{12}$ However, in conjunction with the cyclosporin related arteriolar vasculopathy, ${ }^{7}$ which we have also noted, it appears that cyclosporin may initiate or accentuate vascular damage. We believe that this phlogistic effect is most likely to be mediated by an effect on platelet-endothelial interactions. ${ }^{818}$

We thank Dr David Holt at the Poisons Unit, New Cross Hospital, for measuring cyclosporin concentrations. We thank Professor Cyril Chantler and Dr George Haycock for permission to include their patient (patient 5).

\section{References}

' Shulman H, Striker G, Deeg HJ, Kennedy M, Storb R, Thomas ED. Nephrotoxicity of cyclosporin A after allogeneic marrow transplantation: glomerular thromboses and tubular injury. $N$ Engl J Med 1981;305:1392-5.

2 Atkinson K, Biggs JC, Hayes J, Ralston M, Dodds AJ. Cyclosporin $A$ associated nephrotoxicity in the first 100 days after allogeneic bone marrow transplantation: three distinct syndromes. Br J Haematol 1983;54:59-67.

${ }^{3}$ Taube DH, Welsh KI, Kennedy LA, et al. Successful removal and prevention of resynthesis of anti-HLA antibody. Transplantation 1984;37:254-5.

4 Neild GH, Cameron JS, Ogg CS, et al. Rapidly progressive glomerulonephritis with extensive glomerular crescent formation. $Q J$ Med 1983;52:395-416.

${ }^{5}$ Heyderman E. Immunoperoxidase technique in histopathology: applications, methods and controls. $J$ Clin Pathol 1979;32:971-8.

- Lendrum AC, Fraser DS, Slidders W, Henderson R. Studies on the character and staining of fibrin. J Clin Pathol 1962; 15:401-13.

' Mihatsch MJ, Thiel G, Spichtin HP, et al. Morphological findings in kidney transplants after treatment with cyclosporine. Transplant Proc 1983;15:2821-35.

${ }^{8}$ Neild GH, Ivory K, Williams DG. Glomerular thrombosis and cortical infarction in cyclosporin-treated rabbits with acute serum sickness. Br J Exp Pathol 1984;65:133-44.

' Heptinstall RH. Pathology of the kidney. 3rd ed. Boston: Little, Brown and Co, 1983:907-61.

${ }^{10}$ Kamitsuji H, Kusumoto K, Taira K, Iida Y, Nakajima M, Fukui $H$. Localisation of intra-renal cross-linked fibrin in children with various renal diseases. Nephron 1983;35:94-9.

"Canadian Multicentre Transplant Study Group. A randomized clinical trial of cyclosporine in cadaveric renal transplantation. N Engl J Med 1983;309:809-15.

12 Busch GJ, Reynolds ES, Galvanek EG, Braun WE, Dammin GJ. Human renal allografts. The role of vascular injury in early graft failure. Medicine 1971;50:29-79.

${ }^{13}$ Calne RY, White DJG, Thiru S, et al. Cyclosporin A in patients receiving renal allografts from cadaver donors. Lancet 1978;ii: $1323-7$.

${ }^{14}$ Remuzzi G, Misiani R, Marchesi D, et al. Haemolytic uraemic syndrome: deficiency of plasma factor(s) regulating prostacyclin activity. Lancet 1978:ii:871-2.

is Moncada S, Vane JR. Prostacyclin: its biosynthesis, actions and clinical potential. Philos Trans $R$ Soc Lond [Biol] 1981;294:305-29.

16 Sraer J, Ardaillou N, Sraer JD, Ardaillou R. In vitro prostaglandin synthesis by human glomeruli and papillae. Prostaglandins 1982;23:855-64.

"MacIntyre DE, Pearson JD, Gordon JL. Localisation and stimulation of prostacyclin production in vascular cells. Nature 1978;271:549-51.

${ }^{18}$ Neild GH, Rocchi G, Imberti L, et al. Effect of cyclosporin A on prostacyclin synthesis by vascular tissue. Thromb Res 1983;32:373-9.

Requests for reprints to: Dr GH Neild, St Philip's Hospital, Sheffield Street, London WC2A 2EX, England. 